\title{
Prevalence and associated factors of risky sexual behaviors among undergraduate students in state universities of Western Province in Sri Lanka: a descriptive cross sectional study
}

Upuli Amaranganie Pushpakumari Perera ${ }^{1 *}$ and Chrishantha Abeysena ${ }^{2}$

\begin{abstract}
Background: Risky sexual behaviors (RSB) are becoming an important problem all over the world. RSB are defined as behaviors leading to sexually transmitted diseases and unintended pregnancies. The objective of this study was to determine the prevalence and associated factors of RSB among undergraduate students in state universities of Western Province in Sri Lanka.

Methods: A descriptive cross sectional study was conducted on1575 second and third year undergraduates using stratified cluster sampling of the selected universities. A pretested self-administered questionnaire was used to assess socio-demographic, knowledge attitudes and behavior on reproductive health. RSB was defined as reporting of one or more following behavior/s; having more than one sexual partner, use of alcohol or inability to use condom or other contraceptive methods in sexual activities. The results were expressed as prevalence and its $95 \%$ confidence interval (Cl) of RSB. Multiple logistic regression was performed ascertain the association between RSB and possible associated factors. The results were expressed as adjusted odds ratios (AOR).

Results: Prevalence of RSB in last 1 year and 3 months periods were $12.4 \%,(95 \% \mathrm{Cl}: 11.8-13.1)$ and 12.1\% (95\% Cl: 11.5-12.7) respectively. The significantly associated risk factors for RSB were, attended night clubs in last month $(\mathrm{AOR}=3.58,95 \% \mathrm{Cl}: 1.29-9.88)$, alcohol consumption within last 3 months ( $\mathrm{AOR}=2.67,95 \% \mathrm{Cl}: 1.87-3.80)$ and good knowledge on condoms ( $\mathrm{AOR}=2.82,95 \% \mathrm{Cl}$ : 1.94-4.10). Those who thought religion was very important to their lives (AOR $=0.68,95 \% \mathrm{Cl}: 0.48-0.95)$ was a protective factor.
\end{abstract}

Conclusions: Alcohol consumption and attending night clubs were associated with RSB. Necessary measures should be taken to reduce risk behaviors within university to reduce RSB.

Keywords: Attitudes, Knowledge, Reproductive, Sexual, Undergraduates

\footnotetext{
* Correspondence: tauapp100@gmail.com

${ }^{1}$ Postgraduate Institute of Medicine, University of Colombo, 36/1, Naiwala,

Essalla, Veyangoda, Sri Lanka

Full list of author information is available at the end of the article
}

C The Author(s). 2018 Open Access This article is distributed under the terms of the Creative Commons Attribution 4.0 International License (http://creativecommons.org/licenses/by/4.0/), which permits unrestricted use, distribution, and reproduction in any medium, provided you give appropriate credit to the original author(s) and the source, provide a link to the Creative Commons license, and indicate if changes were made. The Creative Commons Public Domain Dedication waiver (http://creativecommons.org/publicdomain/zero/1.0/) applies to the data made available in this article, unless otherwise stated. 


\section{Plain English summary}

Risky sexual behaviors (RSB) are defined as behaviors leading to sexually transmitted diseases and unintended pregnancies. Currently about 100,000 undergraduate students studying at state universities in Sri Lanka who may be at risk of practicing RSB. This study seeks to determine the prevalence of such behaviors among this group of students.

Data were collected from second and third year undergraduate students with a questionnaire on sexual behaviors, other risk behaviors, knowledge and attitudes on sexual and reproductive health. Of students surveyed $12.4 \%$ were found to practice RSB within the last 1 year period. Several other behaviors such as alcohol consumption within the last 3 months, attending night clubs in last month and those with good knowledge on condoms were associated with RSB. Those who thought religion was very important to their lives were less likely to practice RSB. Suggestions were made to take necessary steps to minimize alcohol consumption within university and outside, to discourage night clubs attendance by facilitating more recreational activities and to promote religious activities.

\section{Background}

Risky sexual behaviors (RSB) are becoming an important problem all over the world. The Centers for Disease Control and Prevention (CDC) defines RSB as Sexual behaviors leading to unintended pregnancies and sexually transmitted infections (STI) include $\mathrm{Hu}$ man immuno-deficiency Virus (HIV) and acquired immuno-deficiency syndrome (AIDS) [1]. It includes having multiple sexual partners, having sex without using a condom or other contraceptive method. In addition to that, several authors have included the following factors in to their definition of RSB: initiation of first sex at early age before 18 years [2, 3], sexual activity done under the influence of alcohol and anal intercourse [4], sexual violence and transactional sex [3] and paid sex [5].

There is limited literature on sexual practices among various population groups in Sri Lanka. The prevalence of risk behavior among adolescents and young adults was higher than the expected level by parents and teachers [6-8]. Global prevalence studies including other Asian countries would give a better estimate of considerably higher RSB in undergraduates $[9,10]$. There is a vast amount of literature on undergraduates' RSB in African countries indicating that higher prevalence of RSB among them ranging from 7 to $47 \%$ [11-17].

Known socio-demographic and economic risk factors associated with RSB are male sex [11, 12, 18], smoking [8, 20], night club attendance [11] and alcohol use $[8,9,19-21]$. In contrast, having a good relationship with friends, peers and parents [9], as well as religiosity [12, 22] have been found to be a protective measure against RSB.

There are more than 105,000 youths studying in universities in Sri Lanka where the majority are not in a relationship [23]. University life is a shift towards greater freedom from family and school backgrounds for most of them. It provides an opportunity to practice new friendships, social mixing and consequently to engage in risky behaviors including RSB [9]. The findings of this study could potentially support to develop programs to reduce RSB and to improve the knowledge and practices via the existing system of tertiary education. Therefore we conducted this study to determine the prevalence and factors associated with RSB among undergraduates in the state universities of the Western Province in Sri Lanka.

\section{Methods \\ Study design}

An institution-based descriptive cross-sectional study was conducted in four state universities in the Western Province of Sri Lanka (Univeristy of Colombo, University of Sri Jayewardenepura, University of Kelaniya and University of Moratuwa), representing around 17\% of total undergraduates enrolled in state universities in the country.

\section{Study population}

The study population was undergraduate students studying in second and third years which were 18,280 in number [23]. Undergraduates from foreign countries and clergymen undergraduates were excluded. First year students were excluded as they are new to the environment. So their risk behaviors may not be due to as the same factors as second and third year students. Fourth and fifth year students were excluded as these advanced years are not conducted in every course. Exclusion of foreign students was done due to their different socio-cultural background.

\section{Sample size and sampling technique}

Calculated sample size was 1314 with expected prevalence of $13 \%$ of heterosexual intercourse without condoms among unmarried, out of school adolescents [7], $1.96 \mathrm{Z}$ value, $3 \%$ of precision and a correction for design effect of 2.45 [24, 25] and $10 \%$ of non-respondents.

A multistage cluster sampling technique with probability proportional to size (PPS) was used to select a representative sample of undergraduates (Fig. 1). A cluster was defined as a tutorial group or a whole batch according to the structure of the selected undergraduates group. The average cluster size was considered as 30 . 


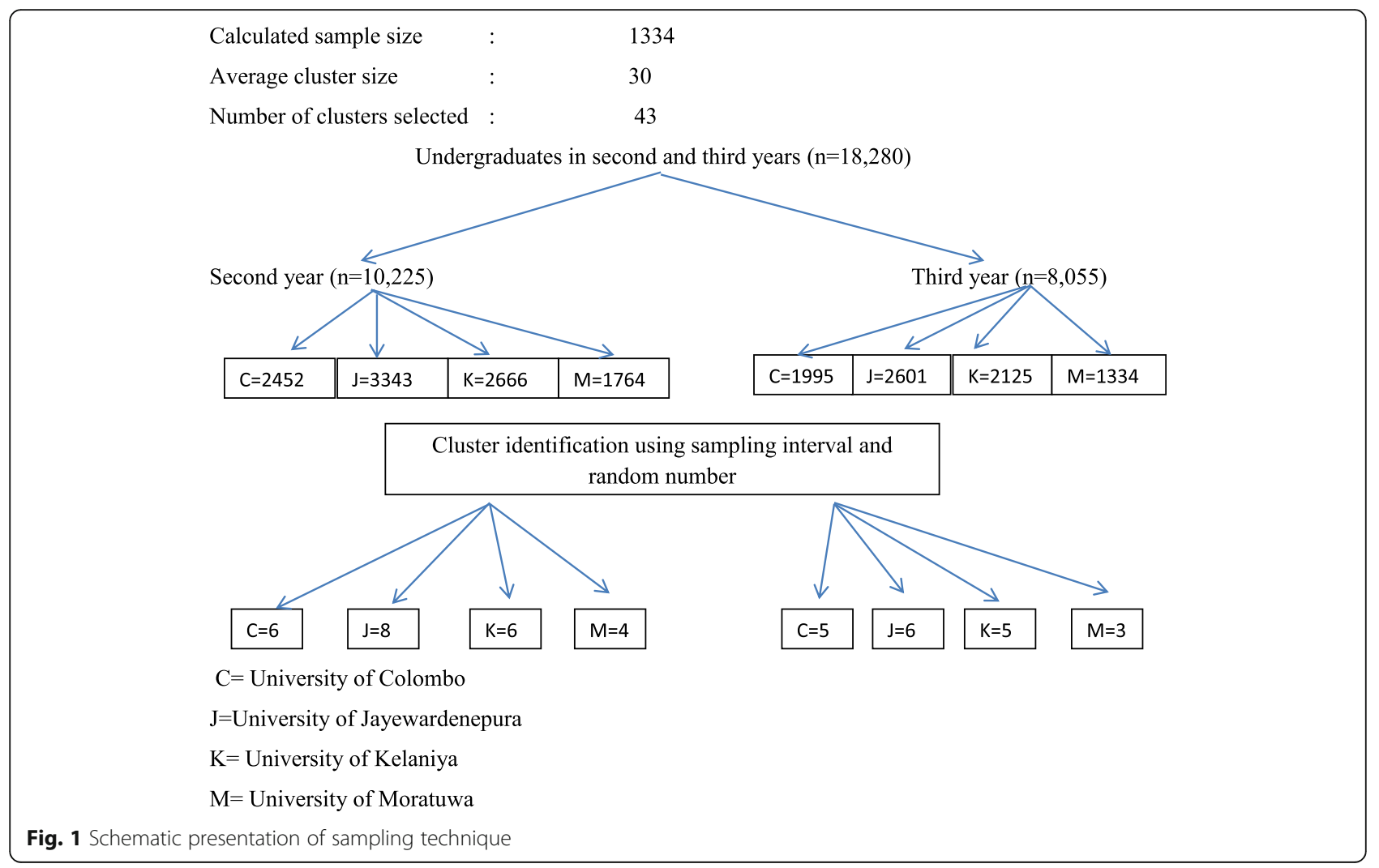

Then we allocated the clusters for each academic year and university according to the proportion of undergraduates. Undergraduates were stratified according to their respective university and academic years and academic streams. Finally clusters were identified within each stratum based on PPS according to the number of students in each university and academic year.

\section{Data collection}

Data were collected on socio-demographic factors, other risk behaviors including consumption of alcohol, smoking and using narcotic drugs, sexual behavior and knowledge and attitudes in selected aspects of reproductive health (RH) among undergraduates. Sri Lanka Behavioral Surveillance Survey questionnaire [26], Youth risk behavior surveillance questionnaire used by CDC [1] and Illustrative Questionnaire for Interview Surveys with Young People [27] were used as guides to develop the questionnaire.

The validity of the questionnaire was ensured by assessing the judgmental validity which included face, content and consensual validity. Validity was determined by assessing the agreement of the experts on whether or not the conceptual definition has been used appropriately in the tool. A multi-disciplinary panel of experts in the fields of public health, reproductive health and language was used for assessment of validity. The questionnaire was forward-translated into Sinhala and back-translated to English. Data were collected using a pre-tested self-administrative questionnaire after obtaining permission. The filled questionnaires in an envelope were collected by trained research assistant. The data collection procedure was supervised by the first author. Informed written consent was obtained from the participants. Ethical clearance was taken from the Ethical Review Committee, Faculty of Medicine, University of Kelaniya.

Knowledge on some aspects of $\mathrm{RH}$ was measured with statements on unsafe abortions, contraceptives including condoms, STIs including HIV/AIDS and sexual and RH rights. Attitudes on RH was measured with statements on contraceptives, condoms and HIV/AIDS which contained five responses; strongly agree, agree, neutral, disagree and strongly disagree.

RSB was defined as reporting one or more following behavior/s; having more than one sexual partner, alcohol use with sexual activities, inability to use condom to prevent STI in sexual activities with commercial sex workers or non-commercial partners, unable to use contraceptive methods to prevent unintended pregnancy in sexual activities with commercial sex workers or 
non-commercial partners. RSB was defined as for the last 1 year and the last 3 months separately.

\section{Data analysis}

Data were analyzed with Statistical Package for Social Science (SPSS) (Version 16). Prevalence and 95\% confidence interval (CI) of RSB were calculated for last 1 year and last 3 months periods separately. Sex specific RSB and university specific RSB was calculated for last 3 months period. To ascertain the association between RSB and other variables binary logistic regression was performed. Variables with $p$ value less than or equal to 0.20 at binary were entered into multiple logistic regression analysis. Hosmer Lemshow goodness of fit with backward elimination was used to test for model fitness. Variables with $\mathrm{p}$ value of $<0.05$ at multiple regression were considered as statistically significant. The results were expressed as Odds Ratio (OR) and adjusted odds ratios (AOR).

\section{Results}

\section{Background information}

The study sample consisted of 1575 undergraduates from four state universities in the Western Province. Majority of respondents were females ( $n=926,58.8 \%)$ and unmarried $(98.5 \%, n=1551)$. Mean age was 23 $(\mathrm{SD}=0.9)$ years. The sample consisted more Sinhalese $(94.1 \%, n=1480)$ than non-Sinhalese and Buddhists (89.8\%, $n=1414$ ) than non-Buddhists. Socio-demographic factors are shown in Table 1.

\section{The prevalence of RSB}

The prevalence of RSB among undergraduates were $12.4 \%(n=196 ;, 95 \%$ CI: $11.8-13.1)$ and $12.1 \%(n=$ 190, 95\% CI: $11.5-12.7)$ for last 1 year and last 3 months respectively. The highest percentage (16.8\%, $n=57$ ) of undergraduates with RSB was in University of Kelaniya followed by University of Sri Jayewardenepura (12.5\%, $n=72)$. Males $(19.1,95 \%$ CI $16.1-$ 22.2) had more RSB than females $(7.2$, 95\% CI $5.5-$ 8.9) $(p<0.001)$.

\section{Sexual behavior of the participants}

In the study sample $21.2 \% \quad(n=334)$ reported ever having had sexual exposure. Males $(32.7 \%, n=211)$ had more ever sexual exposure than females $(13.1 \%$, $n=122) \quad(p<0.001)$. Majority of undergraduates $(63.9 \%, n=205)$ who ever had sexual exposure experienced their first intercourse after 20 years of age. More females $(75 \%, n=87)$ than males $(57.8 \%, n=$ 118) had their first sexual exposure before the age of 20 years $(p=0.002)$. Out of 334 undergraduates had sexual exposure ever, $3.3 \%(n=11)$ stated that their first sexual experience was a forced sex. Majority
(75.4\%, $n=252)$ of the respondent's first sexual partner was a girl/boyfriend.

Out of 334 with had ever sexual exposure only $18 \%$ ( $n$ $=60$ ) of the respondents had used condoms in first sexual intercourse while only $1.5 \%(n=5)$ of the respondents had used alcohol in first sexual intercourse. Out of all undergraduates, $13.7 \%(n=216)$ had more than one life time sexual partners.

Percentage of undergraduates who had sexual intercourse within last 1 year was $87.7 \%(n=293)$ out of 334 respondents who ever had sex. Majority of them had one sexual partner irrespective of whether they have engaged in sexual intercourse in last 1 year or last 3 months. Ninety four (5.96\%) and 79 (5.01\%) respondents had multiple sexual partners within last 1 year and 3 months respectively. The majority $(85.8 \%, n=176)$ of undergraduates those who had sexual intercourse within last 1 year had not used condoms in their last sexual activity. Out of 17 undergraduates that had sexual intercourse with commercial sex worker, $58.8 \%(n=10)$ had used condom at their last sexual activity. The percentage used condoms at last sex with non-commercial sex partners were $12.4 \%(n=24)$.

\section{Factors associated with RSB in bivariate analysis}

Being a male undergraduate and belonging to Sinhala ethnicity showed significant association with RSB in bivariate analysis. As shown in Table 2, RSB for last 3 months was negatively associated with engaging more religious activities and considering religion as more important to their lives. Having to the opportunity to talk with parents and siblings regarding sexual problems showed negative association with RSB.

Further, RSB were significantly associated with undergraduates who attended nightclubs more than once within last month, those who had used internet facilities $>2$ h per day, those who went to cinema $\geq 2$ per months, who had taken alcohol within last 3 months, who had smoked within last 3 months, who had taken ganja (cannabis) within last 3 months and who had physical fight within last 1 year in university (Table 3 ).

Good knowledge on contraceptives, good knowledge on condoms, good knowledge on sexual and RH rights, good overall knowledge on $\mathrm{RH}$, favorable attitudes on contraceptives, favorable attitudes on condoms and favorable overall attitudes on $\mathrm{RH}$ showed statistically significant associations in bivariate analysis with RSB (Table 4).

\section{Factors associated with RSB in multivariate analysis}

Multiple logistic regression model included 1575 participants. RSB during the last 3 months showed significant association with four factors. Those who had taken alcohol within last 3 months (AOR 2.59, 95\% CI: 1.82-3.70), 
Table 1 Socio-demographic characteristics among the undergraduates

\begin{tabular}{|c|c|c|c|}
\hline \multicolumn{2}{|l|}{ Characteristics } & \multirow{2}{*}{$\begin{array}{l}\text { Frequency } \\
645\end{array}$} & \multirow{2}{*}{$\begin{array}{l}\text { Percentage } \\
41.0\end{array}$} \\
\hline Sex & Male & & \\
\hline & Female & 926 & 58.8 \\
\hline \multirow[t]{6}{*}{ Age (in years) } & 21 & 20 & 1.3 \\
\hline & 22 & 449 & 28.5 \\
\hline & 23 & 696 & 44.2 \\
\hline & 24 & 307 & 19.5 \\
\hline & 25 & 83 & 5.3 \\
\hline & 26 & 11 & 0.7 \\
\hline \multirow[t]{2}{*}{ Academic year } & Second & 930 & 59.0 \\
\hline & Third & 645 & 41.0 \\
\hline \multirow[t]{4}{*}{ University } & Kelaniya & 339 & 21.5 \\
\hline & Sri Jayewardenepura & 576 & 36.6 \\
\hline & Colombo & 353 & 22.4 \\
\hline & Moratuwa & 307 & 19.5 \\
\hline \multirow[t]{4}{*}{ Nationality } & Sinhalese & 1480 & 94.1 \\
\hline & Tamil & 58 & 3.7 \\
\hline & Muslims & 33 & 2.1 \\
\hline & Other & 1 & 0.1 \\
\hline \multirow[t]{6}{*}{ Religion } & Buddhism & 1414 & 89.8 \\
\hline & Roman Catholic & 65 & 4.1 \\
\hline & $\begin{array}{l}\text { Non Roman Catholic } \\
\text { Christian }\end{array}$ & 6 & 0.4 \\
\hline & Islam & 45 & 2.9 \\
\hline & Hindu & 39 & 2.5 \\
\hline & Other & 3 & 0.2 \\
\hline \multirow[t]{4}{*}{ Residence } & Own home & 453 & 28.8 \\
\hline & Relative's house & 36 & 2.3 \\
\hline & University hostel & 411 & 26.1 \\
\hline & Boarding place & 671 & 42.6 \\
\hline \multirow{4}{*}{$\begin{array}{l}\text { Academic } \\
\text { streams }\end{array}$} & Art & 516 & 32.8 \\
\hline & Commerce & 424 & 26.9 \\
\hline & Bio Science & 248 & 15.7 \\
\hline & Mathematics & 387 & 24.6 \\
\hline \multirow[t]{3}{*}{ Type of School } & Boys' & 262 & 21.0 \\
\hline & Girls' & 345 & 27.6 \\
\hline & Mixed & 642 & 51.4 \\
\hline \multirow[t]{5}{*}{ Marital status } & Single & 1551 & 98.5 \\
\hline & Married & 13 & 0.8 \\
\hline & Divorced & 1 & 0.1 \\
\hline & Separated & 1 & 0.1 \\
\hline & Living together & 5 & 0.3 \\
\hline
\end{tabular}

those who had attended nightclub more than once in last month (AOR 3.61; 95\% CI: 1.31-9.97), and those who had good knowledge on condoms (AOR 2.91, 95\% CI: 2.00-4.24), showed positive association with RSB. Those who considered the religion to be important to their lives (AOR 0.67, 95\% CI: 0.48-0.95), showed negative association with RSB. (Table 5) Reanalysis of data excluding the variable 'use of alcohol within last three months' had not changed the results.

\section{Discussion}

In this study an attempt has been made to assess the prevalence of RSB and factors associated to RSB among undergraduate students in state universities of Western Province in Sri Lanka.

\section{Prevalence of RSB}

The prevalence of RSB was 12.4 and $12.1 \%$ for last 1 year period and for last 3 months period respectively. Prevalence among male and female undergraduates were 19.1 and 7.2\% respectively. A study carried out among first year Agricultural undergraduates of University of Ruhuna, Sri Lanka reported that $2 \%$ had multiple sexual partners during last 3 months which was considered as a risk behavior [28]. In the present study, having multiple partners during last 3 months was $5 \%$ and the observed difference may be due to the difference of the sample selected i.e. second and third year representing all study streams from four universities. Another study carried out among Ethiopian undergraduates revealed that $18.6 \%$ of them had lifetime multiple sexual partners which was $13.7 \%$ in the present study [29]. Their use of condoms during first sexual intercourse was $11.2 \%$, much lower than the present $18 \%$ figure. Their figure for not using condoms within the last 1 year period was $39.4 \%$ from those who had sex in last 1 year. In the present study, not using condoms in last sexual activity was $85.8 \%$ which was much higher. The figure may be due to the reason that our young people are having "somewhat mutually monogamous" relationships which they would think the need of condom use is unnecessary.

\section{Factors associated with RSB}

In the present study, those who had good knowledge on condoms showed a positive association with RSB. This finding was in line with a study carried out in Washington which discussed an association with knowledge on condoms and condom usage. Failure to use protective method in risk behavior may not be due to the ignorance but may be the inability of perceiving the risk [30]. Undergraduates who had experienced or are interested in sexual behaviors may be enthusiastic in finding more information on preventive measures of STI i.e. usage of 
Table 2 Unadjusted odds ratios for association of risky sexual behavior with socio-demographic, social and economic factors

\begin{tabular}{|c|c|c|c|c|}
\hline \multirow[t]{2}{*}{ Factors } & \multicolumn{2}{|c|}{ Risky sexual behavior } & \multirow{2}{*}{$\begin{array}{l}\text { OR } \\
(95 \% \mathrm{Cl})\end{array}$} & \multirow[t]{2}{*}{$p$ value } \\
\hline & Yes No (\%) & No No (\%) & & \\
\hline \multicolumn{5}{|l|}{ Sex } \\
\hline Male & $123(64.7)$ & $522(37.8)$ & $3.02(2.20-4.15)$ & $<0.001$ \\
\hline Female & $67(35.3)$ & 859 (62.2) & Reference & \\
\hline \multicolumn{5}{|l|}{ Age } \\
\hline$\leq 22$ yrs & $55(29.3)$ & $414(30.0)$ & $1.04(0.74-1.45)$ & 0.83 \\
\hline$>23$ yrs & $133(70.7)$ & $964(70.0)$ & Ref & \\
\hline \multicolumn{5}{|l|}{ Residence } \\
\hline Outside home & $137(72.1)$ & $948(68.5)$ & 1.19 (0.85-1.66) & 0.31 \\
\hline In home & $53(27.9)$ & $436(31.5)$ & Ref & \\
\hline \multicolumn{5}{|l|}{ Religion } \\
\hline Buddhist & $176(92.6)$ & $1238(89.4)$ & $1.50(0.84-2.64)$ & 0.17 \\
\hline Non-Buddhists & $14(7.4)$ & 147(10.6) & Ref & \\
\hline \multicolumn{5}{|l|}{ Ethnicity } \\
\hline Sinhala & $188(98.9)$ & $1292(93.3)$ & $6.77(1.65-27.69)$ & 0.002 \\
\hline Non- Sinhala & $2(1.1)$ & $93(6.7)$ & Ref & \\
\hline \multicolumn{5}{|l|}{ Income } \\
\hline$\leq 50,000$ rupees & $139(77.2)$ & $1055(82.8)$ & $0.70(0.48-1.03)$ & 0.07 \\
\hline$>50,000$ rupees & $41(15.8)$ & 219 (17.2) & Ref & \\
\hline \multicolumn{5}{|l|}{ Financial support } \\
\hline > $3000 \mathrm{Rs} /$ month & $13(9.8)$ & $81(7.8)$ & $1.28(0.69-2.37)$ & 0.43 \\
\hline$\leq 3000 \mathrm{Rs} /$ month & 119(90.2) & $951(92.2)$ & Ref & \\
\hline \multicolumn{5}{|l|}{ Academic year } \\
\hline Second & $112(58.9)$ & $818(59.1)$ & $1.005(0.74-.37)$ & 0.98 \\
\hline Third & $78(41.1)$ & $567(40.9)$ & Ref & \\
\hline \multicolumn{5}{|l|}{ Academic stream } \\
\hline Bio-Science & $26(13.7)$ & $222(16.0)$ & $0.83(0.54-1.29)$ & 0.41 \\
\hline Non Bio-Science & $164(86.3)$ & $1163(84.0)$ & Ref & \\
\hline \multicolumn{5}{|l|}{ School type } \\
\hline Mixed & $70(49.0)$ & $575(51.8)$ & $0.89(0.63-1.26)$ & 0.51 \\
\hline Non-mixed & $73(51.0)$ & $534(48.2)$ & Ref & \\
\hline \multicolumn{5}{|l|}{ Religious activities } \\
\hline More & $58(30.5)$ & $615(44.8)$ & $0.54(0.39-0.75)$ & $<0.001$ \\
\hline Less & $132(69.5)$ & 759 (55.2) & Ref & \\
\hline \multicolumn{5}{|l|}{ Importance of religion } \\
\hline More & $118(62.1)$ & $1084(78.3)$ & $0.46(0.33-0.63)$ & $<0.001$ \\
\hline Less & $72(37.9)$ & $301(21.7)$ & Ref & \\
\hline \multicolumn{5}{|c|}{ Access to talk with relative, } \\
\hline Yes & $110(57.9)$ & $969(70.1)$ & $0.59(0.43-0.80)$ & 0.001 \\
\hline No & $80(42.1)$ & $416(30.0)$ & Ref & \\
\hline \multicolumn{5}{|c|}{ Access to talk with friends } \\
\hline Yes & $177(93.2)$ & $1231(88.9)$ & $1.70(0.95-3.06)$ & 0.07 \\
\hline No & $13(6.8)$ & $154(11.1)$ & Ref & \\
\hline
\end{tabular}


Table 3 Unadjusted odds ratio for association of risky sexual behaviors with other risk behaviors

\begin{tabular}{|c|c|c|c|c|}
\hline \multirow[t]{2}{*}{ Other risk behavior } & \multicolumn{2}{|c|}{ Risky sexual behavior } & \multirow{2}{*}{$\begin{array}{l}\text { OR } \\
(95 \% \mathrm{Cl})\end{array}$} & \multirow[t]{2}{*}{$p$ value } \\
\hline & Yes No (\%) & No No (\%) & & \\
\hline \multicolumn{5}{|c|}{ Attend night clubs in last month } \\
\hline$\geq$ once /month & $9(4.7)$ & $8(0.6)$ & $8.56(3.26-22.46)$ & \\
\hline Not in last month & $181(95.3)$ & $1377(99.4)$ & Ref & $<0.001$ \\
\hline \multicolumn{5}{|l|}{ Using Internet facilities } \\
\hline$\geq 2$ h/day & $88(46.3)$ & $526(38.0)$ & $1.41(1.04-1.91)$ & \\
\hline$<1$ h/day & $102,953.7)$ & $859(62.0)$ & Ref & 0.027 \\
\hline \multicolumn{5}{|c|}{ Monthly frequency of going to cinema halls } \\
\hline$\geq 2$ per month & $34(17.9)$ & $134(9.7)$ & $2.03(1.35-3.07)$ & 0.001 \\
\hline$<1$ per month & $156(82.1)$ & $1251(90.3)$ & Ref & \\
\hline \multicolumn{5}{|c|}{ Had taken alcohol in last three months } \\
\hline Yes & 79 (41.6) & $195(14.1)$ & $4.34(3.14-6.02)$ & $<0.001$ \\
\hline No & $111(58.4)$ & $1190(85.9)$ & Ref & \\
\hline \multicolumn{5}{|c|}{ Had smoked within last three months } \\
\hline Yes & $33(17.4)$ & $76(5.5)$ & $3.62(2.33-5.63)$ & $<0.001$ \\
\hline No & $157(82.6)$ & 1309 (94.5) & Ref & \\
\hline \multicolumn{5}{|c|}{ Had taken Marijuana within last three months } \\
\hline Yes & $15(7.9)$ & $32(2.3)$ & $3.62(1.92-6.83)$ & \\
\hline No & $175(92.1)$ & $1353(97.7)$ & Ref & $<0.001$ \\
\hline \multicolumn{5}{|c|}{ Had physical fighting in last one year in university } \\
\hline Yes & $25(13.2)$ & $35(2.5)$ & $5.84(3.41-10.01)$ & \\
\hline No & $165(86.8)$ & $1350(97.5)$ & Ref & $<0.001$ \\
\hline
\end{tabular}

condoms. Peltzer has stated that those who had recent sexual exposures had correct knowledge on condoms [31].

The present study revealed that those who considered religion is more important to their lives were less likely to be associated with RSB than those who did not. Similar comparable results were also reported among adolescent and young adults in USA [22]. In contrast to the findings, a study done among undergraduates at the University of Kentucky revealed that students with higher religious beliefs but lower religious behaviors were at risk for risky sexual practices [32].

Frequently attending nightclubs showed significant positive association with RSB in the present study. In compatible with these findings, attending night clubs showed significant association with having sex ever, having multiple sexual partners and having sex with commercial sex workers in a study from Ethiopia [33]. The difference in the degree of association may be due to the different definitions of RSB in these two studies. Difference of academic year of selected study participants may have contributed to the observed dissimilarity. The Ethiopian study had selected undergraduates from all 5 years including 1 st, 4 th and 5 th academic years which we have excluded in the present study. Another study conducted among undergraduates had showed different degree of positive association between RSB and attending night clubs [11].

Present study showed a statistically significant positive association with alcohol consumption within the past 3 months' time. The results were compatible with few other studies [16, 25, 34, 35]. Alcohol use together with sexual activities itself are within the definition of RSB in our study, even though none of them had taken alcohol intake as a factor in their definition of RSB. The observed association may be due to an impaired decision making ability and dis-inhibition behavior due to alcohol consumption.

Kebede et al. revealed a positive association between unprotected sex and using alcohol daily [20]. Alcohol consumption has been measured for past 3 months' time while unprotected sex for the period of last 1 year. Undergraduates in England perceived that life style in university provided opportunities for risky sex via high level of alcohol consumption along with other factors like increased sexual opportunities [35]. As described by Cooper, drinking alcohol may have an association that could not be described easily [21]. Therefore there exists 
Table 4 Unadjusted odds ratios for association of RSB with knowledge and attitudes on reproductive health

\begin{tabular}{|c|c|c|c|c|}
\hline \multirow[t]{2}{*}{ Knowledge and attitude aspect } & \multicolumn{2}{|c|}{ Risky sexual behavior } & \multirow{2}{*}{$\begin{array}{l}\text { OR } \\
(95 \% \mathrm{Cl})\end{array}$} & \multirow[t]{2}{*}{$p$ value } \\
\hline & Yes No (\%) & No No (\%) & & \\
\hline \multicolumn{5}{|l|}{ Knowledge on Unsafe abortions } \\
\hline Good & $109(57.4)$ & $730(52.7)$ & $1.21(0.89-1.64)$ & \\
\hline Average $^{a}$ & $81(42.6)$ & $655(47.3)$ & Ref & 0.227 \\
\hline \multicolumn{5}{|l|}{ Knowledge on Contraceptives } \\
\hline Good & $71(37.4)$ & $376(27.1)$ & $1.60(1.17-2.0)$ & \\
\hline Average $^{a}$ & 119 (62.6) & 1009 (72.9) & Ref & 0.003 \\
\hline \multicolumn{5}{|l|}{ Knowledge on Condoms } \\
\hline Good & $145(76.3)$ & $597(43.1)$ & $4.25(3.00-6.04)$ & $<0.001$ \\
\hline Average $^{a}$ & $45(23.7)$ & $788(56.9)$ & Ref & \\
\hline \multicolumn{5}{|c|}{ Knowledge on Sexually Transmitted Infections } \\
\hline Good & $35,918.4)$ & $227(16.4)$ & $1.15(0.78-1.71)$ & 0.481 \\
\hline Average $^{a}$ & $155(81.6)$ & $1158(83.6)$ & Ref & \\
\hline \multicolumn{5}{|l|}{ Knowledge on HIV/AIDS } \\
\hline Good & $125(66.8)$ & $851(62.0)$ & $1.23(0.89-1.71)$ & 0.201 \\
\hline Average $^{a}$ & $62(33.2)$ & $521(38.0)$ & Ref & \\
\hline \multicolumn{5}{|c|}{ Knowledge on Sexual and Reproductive health rights } \\
\hline Good & $58(30.5)$ & $327(23.6)$ & $1.42(1.02-1.98)$ & \\
\hline Average $^{a}$ & $132(69.5)$ & $1058(76.4)$ & Ref & 0.038 \\
\hline \multicolumn{5}{|c|}{ Overall knowledge on Reproductive health } \\
\hline Good & $45(23.7)$ & $241(17.4)$ & $1.47(1.03-2.12)$ & 0.035 \\
\hline Average $^{a}$ & 145(76.4) & $1144(82.6)$ & Ref & \\
\hline \multicolumn{5}{|l|}{ Attitude on contraceptives } \\
\hline Desirable & $75(39.5)$ & $402(29.2)$ & $1.58(1.15-2.16)$ & 0.004 \\
\hline Undesirable & $115(60.5)$ & $974(70.8)$ & Ref & \\
\hline \multicolumn{5}{|l|}{ Attitude on Condoms } \\
\hline Desirable & $121(63.7)$ & $487(35.4)$ & $3.20(2.33-4.38)$ & $<0.001$ \\
\hline Undesirable & $69(36.3)$ & $888(64.6)$ & Ref & \\
\hline \multicolumn{5}{|l|}{ Attitude on HIV/AIDS } \\
\hline Desirable & $93(49.5)$ & $588(42.7)$ & $1.32(0.97-1.78)$ & 0.081 \\
\hline Undesirable & $95(50.5)$ & $788(57.3)$ & Ref & \\
\hline \multicolumn{5}{|c|}{ Attitude on Overall Reproductive health } \\
\hline Desirable & $92(48.4)$ & $388(38.0)$ & $2.41(1.77-3.28)$ & $<0.001$ \\
\hline Undesirable & $98(51.6)$ & $997(72.0)$ & Ref & \\
\hline
\end{tabular}

${ }^{a}$ Satisfactory and poor knowledge were amalgamated as average knowledge

$\mathrm{OR}$, odds ratio, $\mathrm{Cl}$, confidence interval

Table 5 Adjusted odds ratios for Risky Sexual Behavior among undergraduates within last three months

\begin{tabular}{|c|c|c|c|c|c|}
\hline Variable & $\beta$ co-efficient & SE & OR & $95 \% \mathrm{Cl}$ & $p$ value \\
\hline Had taken alcohol within last three months & 0.951 & 0.18 & 2.59 & $1.82-3.70$ & $<0.001$ \\
\hline Attended night clubs more than once in last month & 1.284 & 0.52 & 3.61 & $1.31-9.97$ & 0.013 \\
\hline Good knowledge on condoms & 1.069 & 0.19 & 2.91 & $2.00-4.24$ & $<0.001$ \\
\hline Considered religion was more important to their lives & -0.399 & 0.175 & 0.67 & $0.48-0.95$ & 0.022 \\
\hline
\end{tabular}

Hosmer and Lemeshow Test Chi-square value $3.8, p$ value 0.43

$\mathrm{SE}$, standard error, $\mathrm{OR}$, odds ratio, $\mathrm{Cl}$, confidence interval 
a definite need for further research, both quantitative and qualitative in order to describe relationship between alcohol consumption and RSB.

Given the cross sectional nature of the study design, it was difficult to identify cause and effect association between the variables. As the discussed topic was very sensitive and the information was self-reported, there may be possibility of deliberately hiding of information in relation to unacceptable behavior. The results could be generalized to all the universities in Western Province and all university students in Sri Lanka as participants for the study are from all over the country.

\section{Conclusions}

Risky sexual behavior was prevailing among undergraduates at a rate of $12.4 \%$. Males had more RSB than females. Those who had taken alcohol within last 3 months, had attended night clubs more than once in the last month and had good knowledge on condoms were associated with higher risk of RSB Undergraduates' consideration of the religion as more important to their lives had lower risk with RSB.

Authorities of university and health care providers should consider the need and take necessary actions to establish accessible, affordable RH services within university. They should consider taking necessary steps to minimize alcohol consumption within university and outside society. Authorities within university and outside should discourage night clubs attendance among undergraduates by encouraging more recreational activities with the help of peer leaders, academic and non-academic staff members and other organizations. Religious activities should be promoted within universities and outside.

\section{Abbreviations}

AIDS: Acquired immuno deficiency syndrome; CDC: Centers for disease control and prevention; Cl: Confidence interval; HIV : Human immunodeficiency virus; OR: Odds ratio; PPS: Probability proportionate to size; $\mathrm{RH}$ : Reproductive health; RSB: Risky sexual behaviors; SPSS: Statistical package for social science; STI: Sexually transmitted infections

\section{Acknowledgements}

All the undergraduates who participated for the study and the staff of the Universities, data collectors and the members of the Board of Study in Community Medicine, Postgraduate Institution of Medicine.

\section{Funding}

The Medical Research Institute of the Ministry of Health, Sri Lanka funded for the data collection of the study.

\section{Availability of data and materials}

The datasets used and/or analyzed during the current study are available from the corresponding author on reasonable request.

\section{Authors' contributions}

Both authors have contributed equally to the design the study. UP and CA analyzed and interpreted the data. UP was responsible for the conduct of the literature review and implementation of study and a major contributor in writing the manuscript. All authors read and approved the final manuscript.

\section{Ethics approval and consent to participate}

Administrative clearance was obtained from the Vice Chancellors and Deans of the selected faculties. Informed written consent was obtained from the participants. Ethical clearance was taken from the Ethical Review Committee, Faculty of Medicine, University of Kelaniya.

We allowed participants to complete the questionnaire on their own in privacy, seated with an adequate distance from others. An envelope was given to each participant to hand over the filled questionnaire without others' interferences.

\section{Competing interests}

The authors declare that they have no competing interests.

\section{Publisher's Note}

Springer Nature remains neutral with regard to jurisdictional claims in published maps and institutional affiliations.

\section{Author details}

${ }^{1}$ Postgraduate Institute of Medicine, University of Colombo, 36/1, Naiwala, Essalla, Veyangoda, Sri Lanka. ${ }^{2}$ Department of Public Health, Faculty of Medicine, University of Kelaniya, Kelaniya, Sri Lanka.

Received: 22 June 2017 Accepted: 24 May 2018

Published online: 04 June 2018

\section{References}

1. Brener ND, Kann L, Kinchen SA, Grunbaum JA, Whalen L, Eaton D, et al. Methodology of the youth risk behavior surveillance system. Morb Mortal Wkly Rep. 2004;53(RR-12):1-13.

2. Madise N, Zulu E, Ciera J. Is poverty a driver for risky sexual behavior? Evidence from National Surveys of adolescents in four African countries. Afr J Reprod Health. 2007;11(3):83-98.

3. Abels MD, Blignaut RJ. Sexual risk behavior among sexually active first year students at the University of the Western Cape, South Africa. Afr J AIDS Res. 2011;10(3):255-61.

4. Averett S, Corman H, Reichman NE. Effects of Overweight on Risky Sexual Behavior of Adolescent Girls. https://www.nber.org/papers/w16172. Accessed 24 Dec 2012

5. Silas J. Poverty and Risky Sexual Behaviors: Evidence from Tanzania, ICF International Calverton, Maryland, USA. 2013. pubs/pdf/WP88/WP88.pdf. Accessed 10 Dec 2015.

6. Fernando NS. Sexual behavior and substance abuse among youth in the coastal region in Galle district. Thesis (MD in Community medicine, Postgraduate Institute of Medicine, University of Colombo). 2009.

7. Thalagala N, Rajapaksha L. National survey on emerging issues among adolescents in Sri Lanka. In: UNICEF; 2004.

8. Perera B, Reece M. Sexual behavior of young adults in Sri Lanka: implications for HIV prevention. AIDS Care. 2006;18(5):497-500.

9. Sujay R. Premarital Sexual Behavior among Unmarried College Students of Gujarat, India. In: Health and Population Innovation Fellowship Programme, Working paper. New Delhi: Population Council; 2009.

10. Raj RP, Padam S, Edwin RT. There are too many naked pictures found in papers and on the net : factors encouraging premarital sex among young people of Nepal. Health Sci J. 2010;4(3):162-74.

11. Dingeta T, Oljira L, Assefa N. Patterns of sexual risk behavior among undergraduate university students in Ethiopia: a cross-sectional study. Pan Afr Med J. 2012;12:33.

12. Tura G, Alemseged F, Dejene S. Risky sexual behavior and predisposing factors among students of Jimma University, Ethiopia. Ethiop J Heal Sci. 2012;22(3):170-80

13. Musiime KE, Mugisha JF. Factors associated with sexual behaviour among students of Uganda martyrs university. Int J Public Health Res. 2015;3(1):1-9. www.openscienceonline.com/author/download?paperld=1347\&stateld= 8000. Accessed 10 Jan 2016

14. Soboka B, Kejela G. Assessment of Risky Sexual Behaviors among Arba Minch University Students, Arba Minch Town, Snnpr, Ethiopia. J Child Adolesc Behav. 3(2). https://doi.org/10.4172/2375-4494.1000189. Accessed 17 Jan 2016.

15. Mavhandu-Mudzusi, AH, Asgedom T. The prevalence of risky sexual behaviours amongst undergraduate students in Jigjiga University, Ethiopia Health Sagesoheid. 2016:21 (17):179-86. www.scielo.org.za/pdf/hsa/v21n1/ 56.pdf. Accessed 31 Mar 2016. 
16. Wordofa D, Shiferaw $\mathrm{S}$. Sexual risk behaviors and its associated factors among undergraduate students in Madda Walabu university, Southeast Ethiopia: a facility based cross sectional study. Epidemiology. https://doi.org/ 10.4172/2161-1165.1000207. Accessed 30 Apr 2016.

17. Bayissa D, Mebrahtu G, Bayisa G, Mekuanint Y. Assessment of Early Sexual Initiation and Associated Factors among Ambo University Undergraduate Students, Ambo, Ethiopia. J Health Med Nurs. 2016;25:35-40.

18. Ruangkanchanasetr S, Plitponkarnpim A, Hetrakul P, Kongsakon R. Youth risk behavior survey: Bangkok, Thailand. J Adolesc Health. 2005;36:227-35.

19. Cooper ML. Alcohol use and risky sexual behavior among college students and youth: evaluating the evidence. J Stud Alcohol. 2002;14:101-17.

20. Kebede D, Alem A, Mitike G, Enquselassie F, Berhane F, Abebe Y, et al. Khat and alcohol use and risky sex behavior among in-school and out-of-school youth in Ethiopia. BMC Public Health. 2005;14(5):109.

21. Cooper ML. Does drinking promote risky sexual behavior? A Complex Answer to a Simple Question. Drinking Risk Sexual Behav. 2006;15(1):19-23.

22. Haglund KA, Fehring RJ. The Association of Religiosity, Sexual Education, and Parental Factors with Risky Sexual Behaviors among Adolescents and Young Adults, Nursing Faculty Research and Publications Nursing. https:// epublications.marquette.edu/nursing_fac/3/. Accessed 16 Aug 2012.

23. http://www.ugc.ac.lk/en/statistics/university-statistics-2012.html. Accessed 17 Feb 2013.

24. Center for Research on Environment, Health and Population Activities. Determining an Effective and Replicable Communication Based Mechanism for Improving Young Couples' Access to and Use of Reproductive Health Information and Services in Nepal - An Operations Research Study. http:// citeseerx.ist.psu.edu/viewdoc/download;jsessionid= 9FE1397DOF6752DF473913172427D3A3?doi=10.1.1.175.7549\&rep= rep1\&type=pdf. Accessed 10 Dec 2015.

25. Martiniuk ALD, Steel O'Connor K, King WD. A cluster randomized trial of a sex education program in Belize, central America. Int J Epidemiol. 2003;32: $131-6$.

26. Rawstorne P, Worth H. Sri Lanka Behavioural Surveillance Survey: First Round Survey Results 2006-2007, Colombo Ministry of Healthcare and Nutrition, Sri Lanka. http://www.aidscontrol.gov.lk/images/pdfs/hiv_data/ 2006_2007_BSS_Report.pdf. Accessed 17 Feb 2013.

27. Cleland J. Illustrative Questionnaire for Interview-Surveys with Young People http://www.who.int/reproductivehealth/topics/adolescence/questionnaire. Accessed 21 Jan 2013.

28. Somaratna WA. Study on knowledge and attitudes on HIV/AIDS and current sexual practices among first year agriculture students of university of Ruhuna, Dissertation. 2010 (Diploma in Reprod Health, Postgraduate Institute of Medicine, University of Colombo).

29. Henok A, Kassa A, Lenda A, Nibret A, Lamaro T. Knowledge, attitude and practice of risky sexual behavior and condom utilization among regular students of Mizan-Tepi university, South West Ethiopia Journal of child and adolescent behavior https:/doi.org/10.4172/2375-4494. Accessed 25 May 2016.

30. Morrison DM, Baker SA, Gillmore MR. Sexual risk behavior, knowledge and condom use among adolescents in juvenile detention. J Youth Adolescence. 1994:23(2):271-8.

31. Peltzer K. Knowledge and practice of condom use among first year students at University of the North. Curationis. 2001;24(1):53-7.

32. Prassel HB. The influence of religiosity on risky patterns of drug usage and sexual practices in underage undergraduate students. Theses and Dissertations-Psychology. 2016;102. https://uknowledge.uky.edu/ psychology_etds/102.

33. Mulu W, Yimer M, Abera B. Sexual behaviors and associated factors among students at Bahir Dar University: a cross sectional study. Reprod Health. 2014;11(84). https://doi.org/10.1186/1742-4755-11-84.

34. Fentahum N, Mamo A. Risky sexual behaviors and associated factors among male and female students in Jimma zone preparatory schools, south West Ethiopia: comparative study. Ethiop J Health Sci. 2014;24(1):59-68.

35. Chanakira E, O'Cathain A, Goyder EC, Freeman JV. Factors perceived to influence risky sexual behaviours among university students in the United Kingdom: a qualitative telephone interview study. BMC Public Health. 2014. https://doi.org/10.1186/1471-2458-14-1055.

Ready to submit your research? Choose BMC and benefit from:

- fast, convenient online submission

- thorough peer review by experienced researchers in your field

- rapid publication on acceptance

- support for research data, including large and complex data types

- gold Open Access which fosters wider collaboration and increased citations

- maximum visibility for your research: over $100 \mathrm{M}$ website views per year

At BMC, research is always in progress.

Learn more biomedcentral.com/submissions 